\title{
STRESS AND STRAIN ANALYSIS DURING THE SLEME TUNNEL EXCAVATION
}

\author{
Tomislav Hrestak, Antonia Jaguljnjak Lazarević, Lidija Frgić
}

Original scientific paper The distribution of stresses and strains during the portal section excavation for the right tube of the Sleme Tunnel is analysed by the Finite Element Method (FEM). Results of analyses obtained using 2D and 3D models have been compared to in-situ measurements of tunnel convergence and ground surface settlements. Multistage excavations with pipe roof support of the working face were modelled. The numerical models verified that for this particular case a sufficiently safe and cost-efficient construction technology was applied.

Keywords: Finite Element Method; pipe roof; stress and strain analysis; tunnel excavation

\section{Analiza stanja naprezanja i deformacija tijekom iskopa tunela Sleme}

Izvorni znanstveni članak Analizirano je stanja naprezanja i deformacija tijekom iskopa portalne dionice desne cijevi tunela "Sleme" primjenom metode konačnih elemenata. Napravljena je usporedba rezultata proračuna ravninskog (2D) i prostornog (3D) modela s rezultatima terenskih mjerenja konvergencija u tunelu i slijeganja površine terena. Modelirani su višefazni iskopi s ojačanjem čela cijevnim krovom. Proračunski model je pokazao da je u navedenom slučaju primijenjena dovoljno sigurna i ekonomična tehnologija iskopa.

\section{Ključne riječi: analiza stanja naprezanja i deformacija; cijevni krov; iskop tunela; metoda konačnih elemenata}

\section{Introduction}

A tunnel excavation usually needs comprehensive considerations based on geotechnical and geophysical investigations, related to planned excavation methods and supporting systems, geotechnical measurements inside a tunnel, land surveying of the ground surface and possible influence of the excavation on structures in urban areas. The intensive development of traffic networks often requires excavation in geologically unfavourable conditions. Due to large radii and relatively small road and railroad slope routes, where the ground configuration is hard to be followed, tunnels sometimes need to be excavated even in weak rocks. Tunnels are civil engineering structures surrounded by material of poorly known properties, unlike concrete, wooden or steel structures where the material behaviour is fairly better known. Tunnels are also frequently built in urban areas, where low overburden is not uncommon, which additionally increases the complexity of excavation.

Theoretically, excavations under low overburden are those where the height $\mathrm{H}$ of material layers above the tube is less than the tunnel diameter $D$ (marked in Fig. 1).
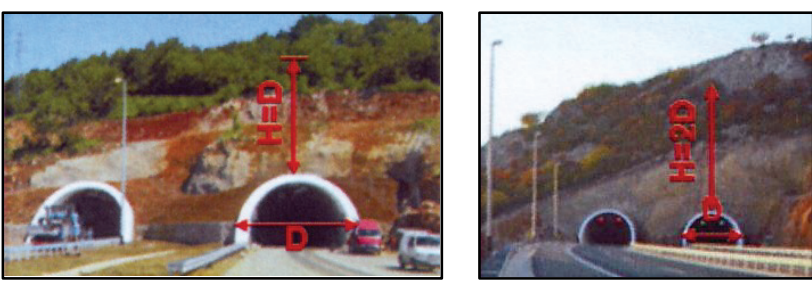

Figure 1Typical tunnel portals [3]

When a tunnel with low overburden in weak and loose rocks is excavated, the possibility of partial or overall working face collapse is increased, thus, additional measures need to be planned and implemented, in particular, including various supporting and multistage excavation strategies.
Excavation with height $H=D$ presents a special challenge and requires particular attention, including the selection and application of distinct technologies, based on previous experience. Designers intentionally avoid portal zone excavations where high portals or side cuts are repeatedly needed. Such approach is easily applied outside urban areas, but there is often no alternative when tunnels are placed in crowded, densely populated regions.

For road tunnels with two lanes (of width D), the New Austrian Tunnelling Method (NATM) defines a height $H \leq 2 D$ as low overburden case, and such approach is commonly accepted in construction practice. For typical cross-sections of road tunnels in Croatia, the width $D \approx 10 \mathrm{~m}$ is usually adopted. Heights of overburden $H=$ $D=10 \mathrm{~m}$ and $H=2 D=20 \mathrm{~m}$ are shown in Fig. 1 .

The NATM method can be adjusted to frequent changes of geological and geotechnical conditions at the working face when the neighbouring geological formation is integrated with the ring-shaped support structure, which simply means that the rock itself is part of the support structure. The majority of time-dependent processes of stress redistribution appear in the bearing rock mass arch a zone around the tunnel opening. The usual term "rock mass arch activation" includes measures taken to maintain and/or increase the rock bearing capacity with the aim of favourably affecting the induced stress state, since the tunnel drilling process changes the in-situ vertical and horizontal stress states $\sigma_{\mathrm{v}}{ }^{\circ}$ and $\sigma_{\mathrm{h}}{ }^{\mathrm{o}}$ into a considerably less favourable induced stress states $\sigma_{\mathrm{v}}$ and $\sigma_{\mathrm{h}}$.

Unlike machine drilling of entire profiles in desirable geological formations, drilling in rock mass with frequent changes of geological and geotechnical conditions along the tunnel line, requires the use of multistage excavation methods. Theoretically, if the radius of the opening is smaller, deformations are usually reduced and despite unfavourable conditions, substantial drilling problems are less expected. Profile development, using a multistage excavation method, is applied when the excavation with low overburden passes through urban areas, weak 
rocks/soils, fault zones, or when excavation is used for underground openings with larger cross-sections. A multistage excavation is usually performed in three major stages: top heading (Stage I), bench (Stage II) and invert (Stage III). In very bad soil/rock conditions, top headings can also be drilled in several stages, with temporary shotcrete invert, which efficiently reduces vertical displacements. The distance between stages depends on geological conditions around the working face. In weak rocks/soils, the bench and invert are excavated in intervals exceeding one tunnel diameter $D$, in order to quickly close the support ring and reach the new equilibrium state, preventing the occurrence of larger convergences.

Most theoretical studies of tunnel excavation with low overburden focus on excavation in urban areas using Tunnel Boring Machines (TBM). The reason is related to the possibility to satisfactorily predict ground settlements as the most frequently noticed side effect of tunnelling within urban areas. This topic points toward the development and use of the TBM with large diameters, which thus indirectly influences the research direction. However, during excavation of shorter tunnels, with frequent changes of the tunnel cross-section, area and side passages, the use of TBM is still much more expensive than excavation using the standard NATM.

Referring to the NATM, authors usually focus on cases of low overburden and the use of NATM in weak rock masses and urban areas, where NATM is already used instead of the TBM. Croatian authors have also published similar studies $[10,16]$, describing examples of tunnel design and construction. Several authors have analysed difficulties, which occurred during excavation of tunnels with low overburden using the NATM, frequently caused by insufficient knowledge about the method [1].

The highest risk of excavation in weak rocks with low overburden is related to large ground settlements, since consequences may sometimes be very dangerous (Fig. 2), even disastrous, causing human casualties. Therefore, the excavation methods chosen need to ensure a safe work environment and minimum settlements, in function of geological and geotechnical properties of the rock mass, tunnel cross-section and excavation technology used.

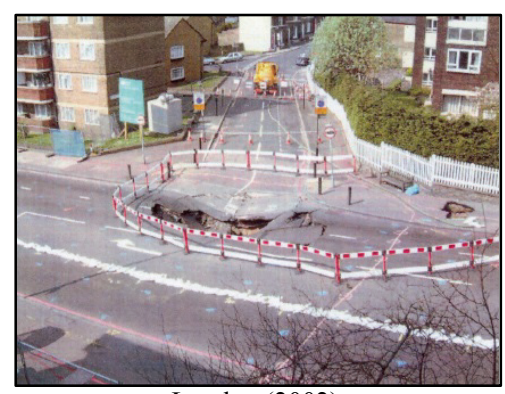

London (2002)

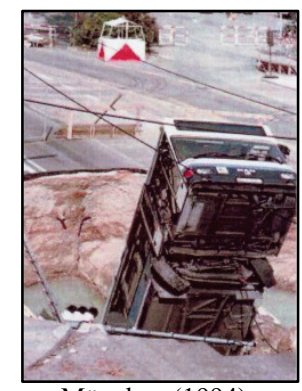

München (1994)
Figure 2 Consequences of large ground settlements during tunnel excavation in urban areas $[1]$

If construction activities accomplished along the tunnel line are of high quality, possible surprises during excavation can be prevented. However, partial collapses occasionally occurred, because surprising situations in tunnelling practice are not rare.
An overall analysis of potentially endangered structures, which might be seriously affected by underground excavations, needs to be carried out before the excavation starts. In the damage classification of these structures, it is necessary to clearly separate damage of load-bearing structural parts, which could ultimately cause partial or total collapse of the structure, from less dangerous damage of secondary or non-structural members.

During tunnel excavations, ground settlements are always systematically measured (by levelling technique using GPS - Geodetic Positioning System), while inside the tunnel, optical 3D measurements of point displacements on the excavation contour (measurement of profile convergence) are often applied.

Ground settlements, caused by tunnel excavations at a certain distance, gradually increase closer to the working face. To reduce settlements and stabilise the excavation, the rock mass needs to be stiffened during the excavation process by grouting, pipe roof installation, soil freezing or core stiffening using fiberglass pipes [12]. This paper discusses use of pipe roof as rock stiffener [7].

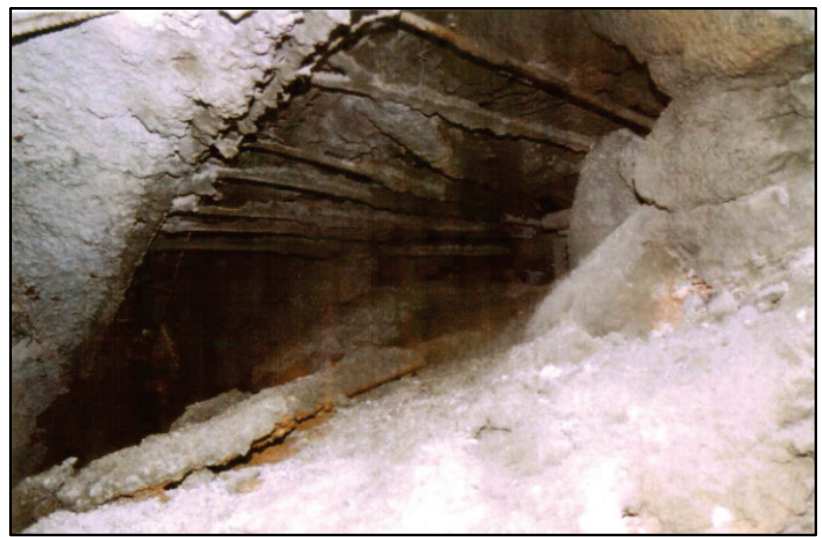

Figure 3 Protection of excavation by forepoling [3]

The pipe roof method is a modern version of forepoling (using steel rods and breakdown sheets, Fig. 3 ), an old mining method of working face protection during rock mass excavation, against the collapse of surrounding material and for the easier installation of support systems.

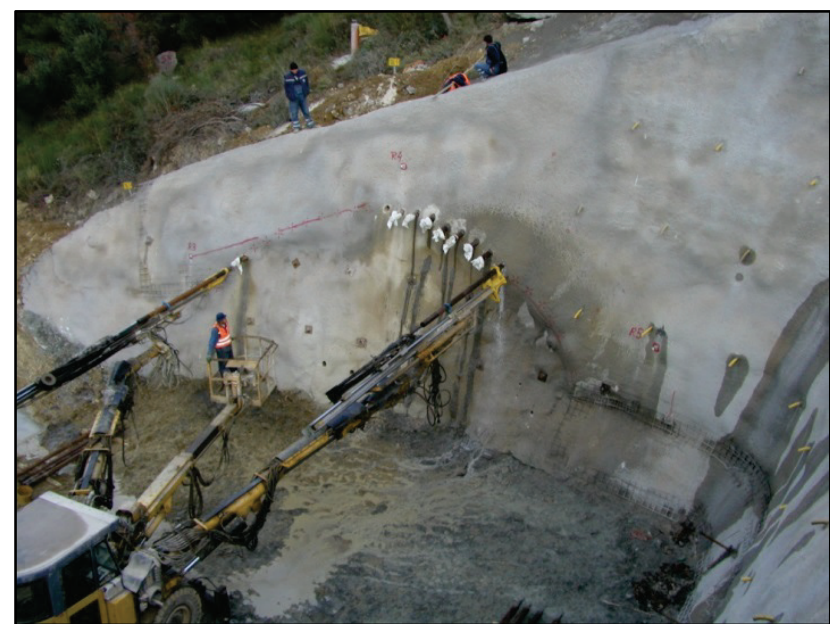

Figure 4 Pipe roof installations [3] 
In particular, to apply the pipe roof method (Fig. 4), grout-mix filled perforated steel pipes are embedded along the tunnel outline in the direction of excavation progress, such that a grouted zone is created, presenting a protective arch under which the excavation progresses $[11,13]$. Even after the geotechnical measurements have been completed, the actual effect of a pipe roof installation can only be estimated by a backward analysis, since the protective behaviour depends on rock type, number of installed pipes, diameter of rock bolt walls and the adopted excavation method.

\section{Land surveying results}

The Sleme Tunnel is located at the Vrata - Delnice section of the Rijeka - Zagreb Highway. The $835 \mathrm{~m}$ long left tube was finished in 1995, and the $858 \mathrm{~m}$ long right tube in 2008. The right tube portal excavation was based on known geology, using the pipe roof strategy.

The tunnel line passes through the Lower Jurassic carbonate sediments - Liassic limestones with dolomite interlayers. The lime stones are light to dark grey coloured, often recrystallized, with rarely encountered fossil contents, stratified with approximately $0,50 \mathrm{~m}$ thick, occasionally hardly noticeable layers, fissured and fractured due to subsequent tectonic activities. In the ground surface zone, the limestone is highly karstified, with large, extremely opened cracks-characteristics that are also noticed during the tunnelling process. The crack filling material consists of high plasticity clay and up to 5 $\mathrm{mm}$ thick calcite layers. Clay is also encountered in the form of clusters, lenses and interlayers. The soil profile is mostly covered with fine detritus and clays-sandy material. The rock mass is heterogeneous and consists of clay, sand and loose karst rocks.

The area in which the Sleme Tunnel was built is tectonically highly fractured and belongs to the geotectonic unit of the Dinaric carbonate platform. Generally, the area is characterised by the highly variable orientation of discontinuities within a relatively small region, indicating an intensive tectonic activity, as actually confirmed during drilling of both tunnel tubes.

The measurements were carried out in the west portal. Since the entire section was at risk of working face collapse, a pipe roof stiffener at the top heading arch, consisting of $\varnothing 114,3 / 6,3 ; 15 \mathrm{~m}$ long steel pipes filled with cement grout, was installed.

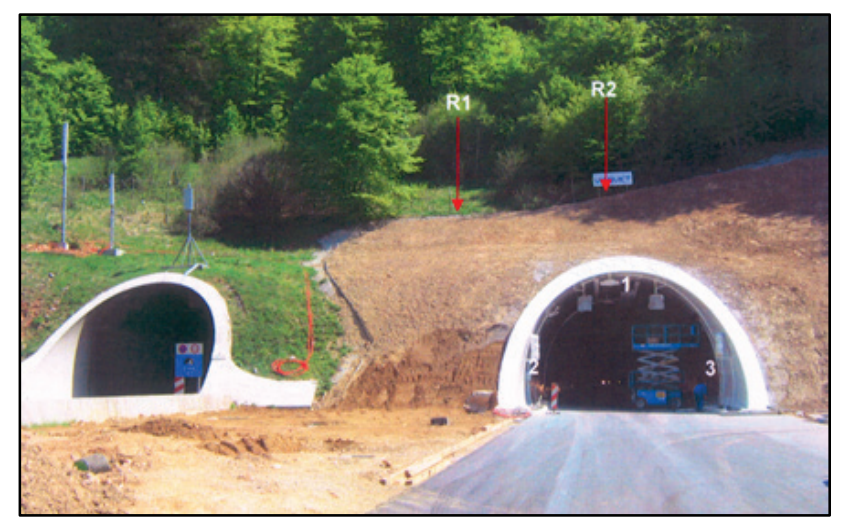

Figure 5 The Sleme Tunnel portal with marked positions of the measuring points $1,2,3, \mathrm{R} 1$ and $\mathrm{R} 2$ of the right tube
The excavation outline displacements were measured with optical 3D method in three points: at point 1 (the top heading apex), and at points 2 and 3 (the bench sides); Figs. 5 and 6.

Settlements were measured using optical methods. Two benchmarks were installed at the chainage $34+961,50$ of the west portal, $10 \mathrm{~m}$ from the excavation starting point. The benchmark installed in the tunnel axis is $\mathrm{R} 2$, while the benchmark $\mathrm{R} 1$ is placed 8,50 m left from the tunnel axis. Positions of benchmarks R1 and R2 are marked in Figs. 5 and 6 . The obtained results are given in Tab. 1.

Table 1 Results of measurements for profile convergence and settlements during the Sleme Tunnel right tube excavation

\begin{tabular}{|c|c|c|c|}
\hline Chainage & $\begin{array}{c}\text { Measurement } \\
\text { of }\end{array}$ & $\begin{array}{c}\text { Overburden } \\
(\mathrm{m})\end{array}$ & $\begin{array}{c}\text { Displacement } \\
u_{x} ; u_{v} ; u_{z}(\mathrm{~mm})\end{array}$ \\
\hline $34+962,50^{*}$ & Convergence & 8,5 & $3 ;-12 ; 8$ \\
\hline $34+975,00^{*}$ & Convergence & 11,0 & $7 ;-5 ; 3$ \\
\hline $34+985,00$ & Convergence & 17,0 & $5 ;-4 ; 3$ \\
\hline $34+996,00^{*}$ & Convergence & 21,0 & $3 ;-2 ; 3$ \\
\hline $34+961,50^{*}$ & Settlement & 8,0 & $0 ;-17 ; 0$ \\
\hline
\end{tabular}

* Numerical calculations for 10 and $20 \mathrm{~m}$ overburden height.

For comparison purposes, the largest measured horizontal (transverse) displacement of the left tube, $25 \mathrm{~m}$ apart from the entrance [8], in identical rock mass, was $20,42 \mathrm{~mm}$, which is considerably more than the displacements in the right tube $(3 \div 7 \mathrm{~mm})$. Many problems were encountered during the left tube excavation, and the top heading arch was stiffened by forepoling (Fig. 3). Minor convergences in the right tube are caused by the application of the pipe roof.

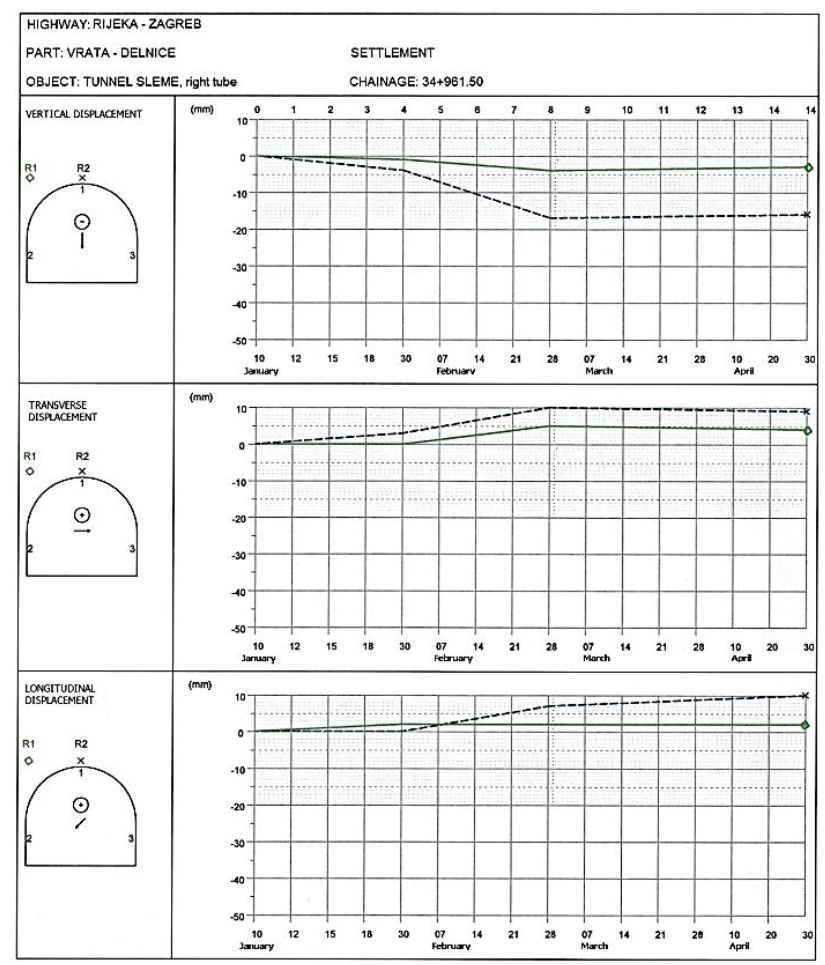

Figure 6 Settlements measured at chainage 34+961,50

\section{Numerical model of excavation process}

An important role in the selection of an excavation method is partially governed by numerical strategies used 
to model excavation in rock mass, always based on geotechnical data and experiences from the previously constructed tunnels [2]. However, difficulties often arise and some real problems encountered in the numerical modelling of weak rocks have previously been described [6]. Numerical analysis, along with geotechnical measurements, provides a safer and more cost-efficient design of tunnels and other underground structures [10]. The evaluation of actual mechanical properties of rock masses is not a straightforward task [9] and even extensive field investigations do not guarantee the completeness and precision of important data. The tunnel construction process is accompanied by problems of highly varying physical and mechanical properties of the rock mass that may result in sudden changes of geological conditions, which, in turn, have a major impact on the tunnel excavation strategy. Stress variations within the rock mass/soil quite often result in damage of the working face, usually when reactive pressure of the primary support to the rock mass is not sufficient. A lower overburden causes a less favourable stress state due to the heterogeneous nature of the rock mass, lower selfsupporting capacity and impacts from ground surface sources (for example, watercourses, structural loads or dynamic loads from the roads).

Stress and strain analyses, based on the Finite Element Method (FEM) have entirely been performed using Sage Crisp 4 for 2D models [15] and Plaxis 3D Tunnel for 3D models [14].

Calculations were carried out for 10 and $20 \mathrm{~m}$ high overburden, for the case of three-stage excavation, firstly without pipe roof (Case a), then with pipe roof in top heading arch - concept applied (Case b), as well as for two-stage excavation (top heading with bench and invert) with pipe roof and $2 \mathrm{~m}$ long invert excavation stage (Case c). The two-stage excavation with pipe roof stiffener and $4 \mathrm{~m}$ long invert excavation stage (Case d) was finally realised.

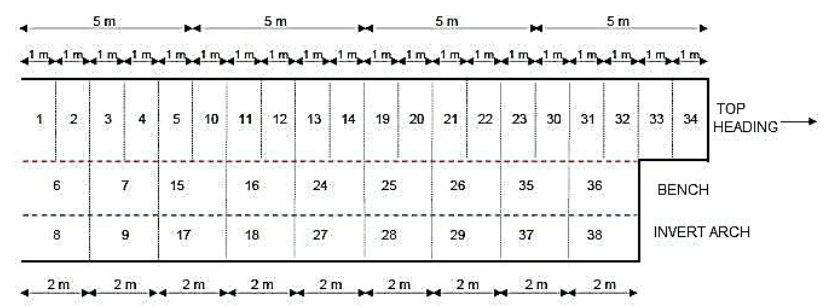

Figure 7 Three-stage profile excavations for 3D calculation

The computational model of three-stage excavation (top heading, bench and invert), using NATM, consists of six phases (Fig.7):

1) Top heading excavation

2) Shotcrete placement into the top heading

3) Bench excavation

4) Shotcrete placement into the bench

5) Invert excavation ( 2 m excavation stage)

6) Shotcrete placement into the invert.

In the first step, the top heading excavation and shotcrete support on a $5 \mathrm{~m}$ long section, with $1 \mathrm{~m}$ long cycle step (excavation and support) were simulated. Then, excavation and shotcrete supporting the bench on a $4 \mathrm{~m}$ long section were simulated. The cycle step was $2 \mathrm{~m}$.
Next, the excavation and shotcrete supporting the invert on a $4 \mathrm{~m}$ long section were simulated, with $2 \mathrm{~m}$ long cycle step. A new top heading, bench and invert excavation cycle then followed until the top heading length reached $20 \mathrm{~m}$ and the bench and invert length $18 \mathrm{~m}$ accordingly. The total number of excavation cycles was 38 , and the total number of 3D calculation stages 76 . A model was created for one-half of the excavated cross-section, since the tunnel is symmetrical around the $y z$ plane (Fig. 8).

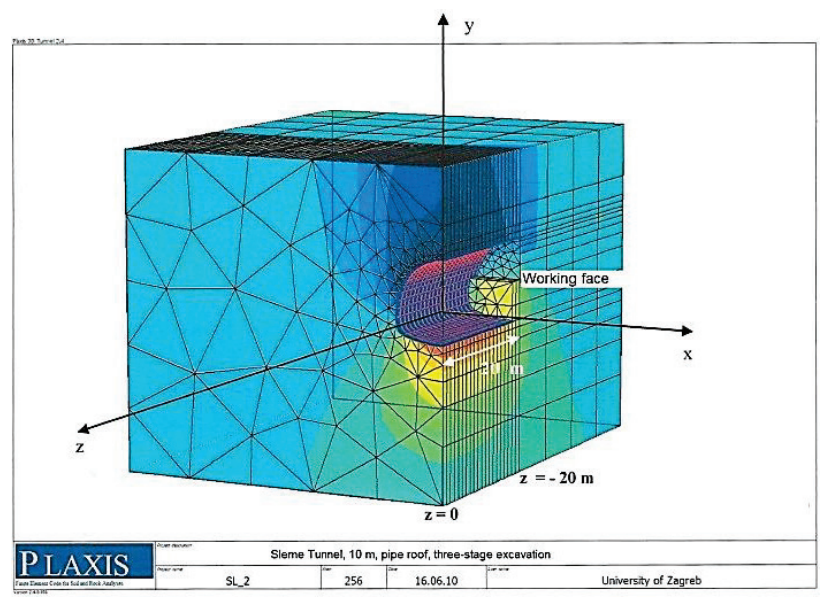

Figure 8 Position of plane $z=0$ (excavation of the whole profile) and $z=-20 \mathrm{~m}$ (at the working face)

Given that results for several cross-sections with coordinates corresponding to excavation stages can easily be obtained numerically, cross-sections at $z=0$ and $z=-20$ $\mathrm{m}$, respectively, are selected to represent calculations for the initial plane as well as for the excavated and supported part of the tunnel located $20 \mathrm{~m}$ from the working face. Fig. 8 shows position of these planes.

Table 2 Physical and mechanical properties of the rocks mass, pipe roof and primary support

\begin{tabular}{|c|c|c|c|}
\hline & $\begin{array}{c}\text { Rock mass }- \\
\text { portal zone }\end{array}$ & $\begin{array}{c}\text { Pipe roof - } \\
\text { stiffened } \\
\text { rock mass }\end{array}$ & $\begin{array}{c}\text { Primary } \\
\text { support }- \\
\text { shotcrete }\end{array}$ \\
\hline $\begin{array}{c}\text { Modulus of } \\
\text { elasticity } E(\mathrm{MPa})\end{array}$ & 300 & 19900 & 3000 \\
\hline $\begin{array}{c}\text { Poisson } \\
\text { coefficient } v(-)\end{array}$ & 0,25 & 0,25 & 0,20 \\
\hline $\begin{array}{c}\text { Unit weight } \\
\rho\left(\mathrm{kN} / \mathrm{m}^{3}\right)\end{array}$ & 26,5 & 19,2 & 25,0 \\
\hline $\begin{array}{c}\text { Angle of internal } \\
\text { friction } \varphi\left(^{\circ}\right)\end{array}$ & 28 & - & - \\
\hline
\end{tabular}

Physical and mechanical properties of the portal zone rock mass $[4,5]$, pipe roof and primary support adopted are given in Tab. 2. The Mohr-Coulomb elastic, perfectly plastic model for the rock mass and an isotropic, linearly elastic model for the primary support is used.

The pipe roof consists of 29 steel pipes $\varnothing 114,3 / 6,3 ; 15$ $\mathrm{m}$ long, filled with a cement grout mixture. The shotcrete thickness is $20 \mathrm{~cm}$, and the rock mass stiffener using a pipe roof in the top heading arch is $50 \mathrm{~cm}$ thick, which approximately corresponds to the as-built situation. Since there is no general rule for the calculation of pipe roof stiffeners, an approximate method was used to calculate the modulus of elasticity according to [6], Tab. 3, where the weak rock mass was replaced by a system comprising 
steel pipes and grout. The corresponding volume density of the stiffened zone is $19,2 \mathrm{kN} / \mathrm{m}^{3}$.

Table 3 Calculation of the modulus of elasticity of the pipe roof stiffener

\begin{tabular}{|c|c|c|c|}
\hline \multirow{2}{*}{ Element } & $\begin{array}{c}\text { Surface area } \\
\left(\mathrm{m}^{2}\right)\end{array}$ & $\begin{array}{c}\text { Modulus of } \\
\text { elasticity (MPa) }\end{array}$ & Product \\
\cline { 2 - 4 } & $\mathrm{a}$ & $\mathrm{b}$ & $\mathrm{a} \cdot \mathrm{b}$ \\
\hline Pipes & 0,06 & $210 \mathrm{E}+03$ & $12,60 \mathrm{E}+03$ \\
\hline Grout mix & 5,94 & $18 \mathrm{E}+03$ & $106,92 \mathrm{E}+03$ \\
\hline Sum: & 6,00 & - & $119,52 \mathrm{E}+03$ \\
\hline $\begin{array}{c}\text { Rock mass } \\
\text { stiffened with } \\
\text { pipe roof }\end{array}$ & & $19,90 \mathrm{E}+03$ & \\
\hline
\end{tabular}

The results of numerical calculations (stresses, vertical displacements and ground settlements) are given in related diagrams and tables. For the case of two-stage excavation of the whole profile, stiffened with the pipe roof (2D calculation), effective vertical stresses (a) and vertical displacements (b) in the case of $10 \mathrm{~m}$ overburden are given in Fig. 9.

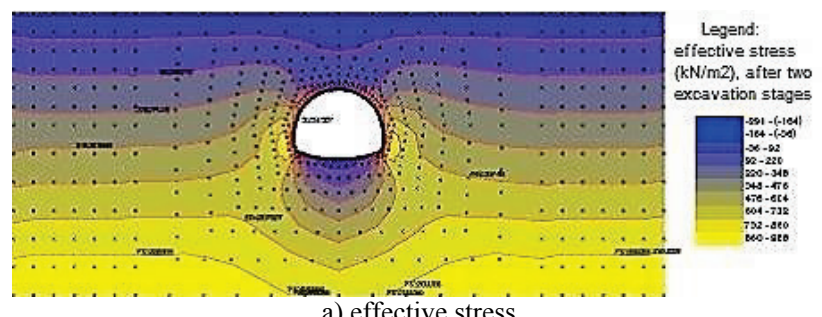

a) effective stress

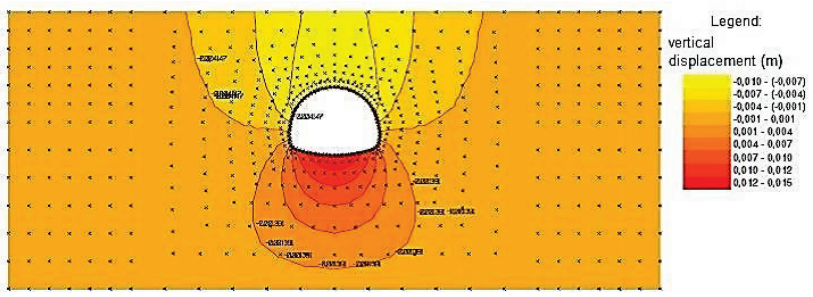

b) vertical displacement

Figure 9 Two-stage excavation with pipe roof as stiffener $(10 \mathrm{~m}$ overburden)

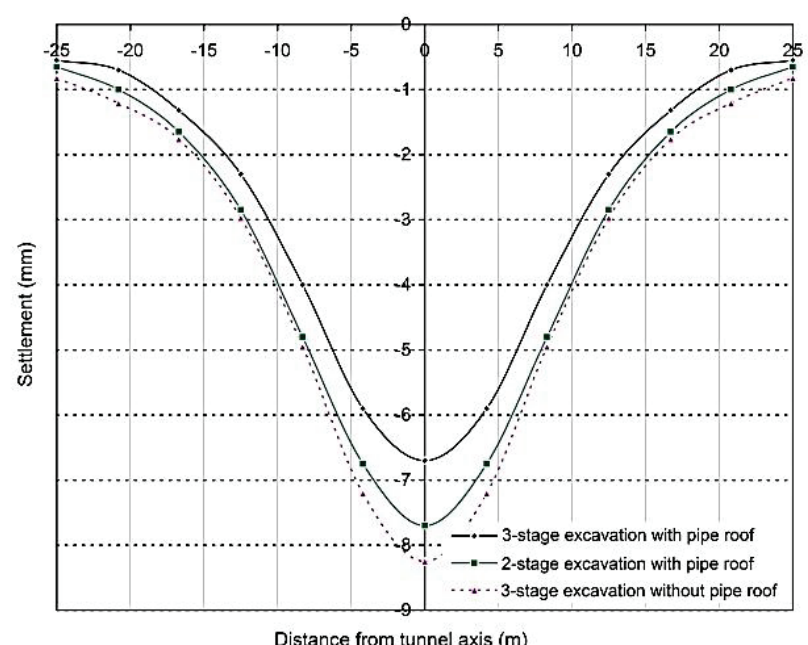

Figure 10 Ground surface settlement after excavation of all stages, 2D calculation

The results of 2D analyses, i.e. ground surface vertical displacements-settlements with $10 \mathrm{~m}$ high overburden after excavation of all stages, are shown in Fig. 10.

The results of ground surface settlements, obtained using 3D models, are given in Fig. 11, visibly reflecting the beneficial effect of the pipe roof stiffener.

The pipe roof effectively decreases convergences in the tunnel and, evidently, reduces ground settlements.

In real conditions, the influence of an underground opening on the settlements reaches a distance approximately equal to the radius of the rock material plastification, which, in turn, depends on the equivalent radius of the opening. If overburden is increased, the pipe roof effect on the settlement decreases. Hence, for higher overburden, the pipe roof reduces convergences in the top heading.

Values of vertical displacements of the top heading apex and ground surface after the excavation of the whole profile $(20 \mathrm{~m}$ from the working face in plane $z=0$ ), obtained numerically, are given in Tab. 4. Results are given for three-stage excavation (top heading, bench, invert), using the NATM method: without pipe roof (Case a) and with pipe roof as stiffener (Case b, Fig. 7 - concept adopted), as well as for two-stage excavation (top heading with bench and invert) with pipe roof and $2 \mathrm{~m}$ (Case c) or $4 \mathrm{~m}$ (Case d) long invert excavation stage (Fig. 12 layout).

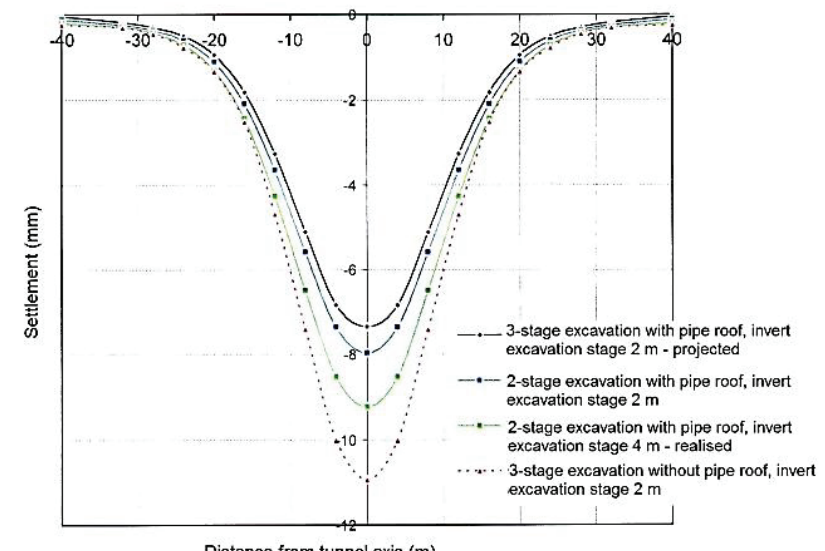

Figure 11 Ground surface settlement after excavation of all stages, 3D calculation

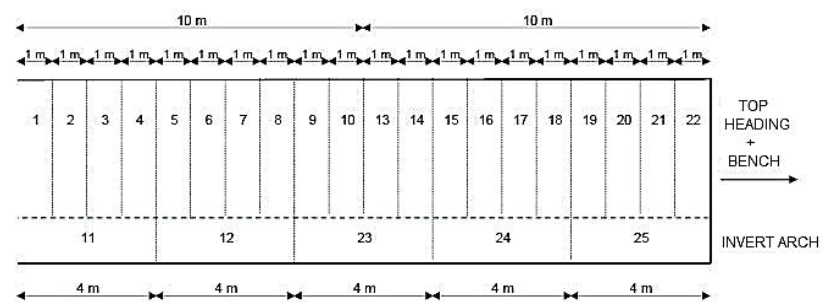

Figure 12 Two-stage profile excavations for 3D calculation

The difference in total vertical displacements for twostage excavation with $2 \mathrm{~m}$ and $4 \mathrm{~m}$ long invert excavation stage is $1,3 \mathrm{~mm}$ for settlements, and 1,4 $\mathrm{mm}$ for the top heading apex. The measurements and calculations indicate that an optimum length of invert excavation stage for the contractor would be $4 \mathrm{~m}$. Furthermore, a shorter invert excavation stage results in less intensive overall convergence. 
Table 4 Vertical displacements $u_{y}(\mathrm{~mm})$ at characteristic points

\begin{tabular}{|c|c|c|c|c|c|}
\hline & Calculation & No pipe roof & \multicolumn{3}{|c|}{ Pipe roof } \\
\hline & & 3-stage & 3-stage & 2 -stage & 2-stage \\
\hline Point & & Case a & Case b & Case c & Case d \\
\hline \multicolumn{6}{|l|}{ Overburden $10 \mathrm{~m}$} \\
\hline Ground surface & 2D & $-7,5$ & $-6,7$ & & \\
\hline \multirow[t]{2}{*}{ Top heading apex } & 2D & $-11,2$ & $-8,6$ & & \\
\hline & & & & $\begin{array}{c}\text { Invert excavation } \\
\text { stage } 2 \mathrm{~m}\end{array}$ & $\begin{array}{c}\text { Invert excavation } \\
\text { stage } 4 \mathrm{~m}\end{array}$ \\
\hline Ground surface & $3 \mathrm{D}^{*}$ & $-9,5$ & $-8,7$ & $-9,0$ & $-9,9$ \\
\hline Top heading apex & $3 \mathrm{D}^{*}$ & $-18,8$ & $-15,6$ & $-15,7$ & $-17,0$ \\
\hline \multicolumn{6}{|l|}{ Overburden $20 \mathrm{~m}$} \\
\hline Ground surface & $2 \mathrm{D}$ & $-9,0$ & $-7,8$ & & \\
\hline \multirow[t]{2}{*}{ Top heading apex } & $2 \mathrm{D}$ & $-19,2$ & $-13,7$ & & \\
\hline & & & & $\begin{array}{c}\text { Invert excavation } \\
\text { stage } 2 \mathrm{~m} \\
\end{array}$ & $\begin{array}{c}\text { Invert excavation } \\
\text { stage } 4 \mathrm{~m} \\
\end{array}$ \\
\hline Ground surface & $3 \mathrm{D}^{*}$ & $-9,5$ & $-8,7$ & $-9,0$ & $-9,9$ \\
\hline Top heading apex & $3 \mathrm{D}^{*}$ & $-18,8$ & $-15,6$ & $-15,7$ & $-17,0$ \\
\hline
\end{tabular}

In addition to the vertical displacement $u_{y}$ and the excavation cross-section convergences $u_{x}, 3 \mathrm{D}$ stress and strain analysis is also used to calculate displacements at the working face $u_{z}$ (pre-convergence, Fig. 13), which are particularly important during excavation in weak rocks/soils, since such information permits quick safety actions, if required. Related to Fig. 13, calculated displacements $u_{x}$ corresponding to the invert, where no ground stiffener has been adopted, are larger. Therefore, at this stage of excavation, it is important to finalise the ring closure as soon as possible. The calculated preconvergence $u_{z}$ ahead of the excavation face is equal to 2 $\div 3 \mathrm{~mm}$; therefore, the core stiffener is actually not needed.

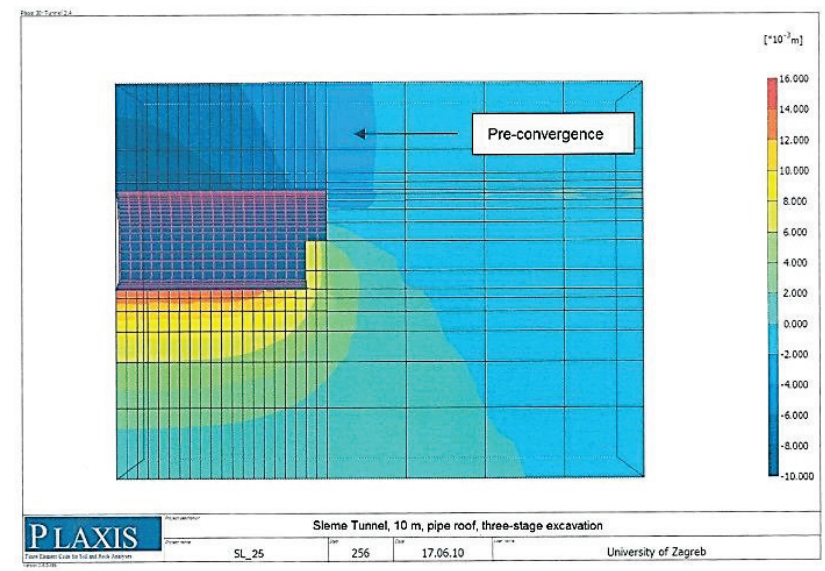

Figure 13 Vertical displacements $u_{y}$ in longitudinal section (overburden height $10 \mathrm{~m}$, pipe roof)

If sufficiently small strains are confirmed by continuous geotechnical measurements, a multistage excavation could be carried out in a smaller number of stages.

Results of 2D and 3D numerical calculations are compared to the results of measurements at chainages $34+962,50$ and $34+975,00$ for a $10 \mathrm{~m}$ high overburden and the actual two-stage excavation with pipe roof and 4 $\mathrm{m}$ long invert excavation stage (Tab. 5).

The results of $3 \mathrm{D}$ calculation for the $10 \mathrm{~m}$ high overburden are in good agreement with measured convergences. The difference in vertical displacements $u_{y}$ is $-0,6 \mathrm{~mm}$, while the difference in transverse $u_{x}$ and longitudinal $u_{z}$ displacements is only $2 \mathrm{~mm}$, which may be considered negligible.

Table 5 Comparison of measured and calculated displacements

\begin{tabular}{|c|c|c|c|}
\hline $\begin{array}{c}\text { Overburden } \\
10 \mathrm{~m}\end{array}$ & $\begin{array}{c}\text { Vertical } \\
u_{v}(\mathrm{~mm})\end{array}$ & $\begin{array}{c}\text { Transverse } \\
u_{x}(\mathrm{~mm})\end{array}$ & $\begin{array}{c}\text { Longitudinal } \\
u_{z}(\mathrm{~mm})\end{array}$ \\
\hline Measured & $-12,0(100 \%)$ & $7,0(100 \%)$ & $8,0(100 \%)$ \\
\hline 2D & $-9,7(81 \%)$ & - & - \\
\hline 3D & $-11,4(95 \%)$ & $9,0(128 \%)$ & $10,0(125 \%)$ \\
\hline
\end{tabular}

With such convergences (maximum $12 \mathrm{~mm}$; Tab. 5), a $0,20 \mathrm{~m}$ thick support system is sufficiently flexible to ensure that support failure is not likely to occur, which is in accordance with the NATM principles. The same applies to the $20 \mathrm{~m}$ high overburden. The highest calculated tunnel convergence for the two-stage excavation is $17 \mathrm{~mm}$, which is in good agreement with measured values. Calculated and measured displacements indicate that, adopting a pipe roof protection system, it is possible to realize a more cost-efficient tunnel excavation, consisting of fewer stages, i.e. implementing two instead of three design steps. Such approach is commonly accepted for the excavation of portal sections in weak and weathered rocks.

\section{Conclusion}

The excavation of a tunnel with low overburden is a complex design 3D problem. In such conditions, the rock mass is often very heterogeneous and has variable physical and mechanical properties. Additionally, it is prone to various influences from the ground surface and, thus, potentially unstable. Practice shows that, even if the rock mass is thoroughly investigated, it is still not always possible to predict all the geological "pitfalls" from the underground. Sudden and unpredicted changes of rock mass properties could, in the worst case scenario, cause tunnel collapse and structural damage of buildings due to ground failure.

Numerical models permit to predict, at least approximately, the rock mass response to tunnel profile excavations. An advantage of the 3D FEM analysis is not only the possibility to model the excavation process by stages, but also to account for changes in excavation stage lengths for particular design phases (top heading, bench 
or invert). The excavation stage is commonly determined empirically, in line with some of the engineering rock mass classifications or based on in-situ modifications of excavation stages, according to data from permanent geotechnical measurements. In the case of the "Sleme" tunnel, founded on broad experience, the contractor had decided to disregard the planned realisation using a threestage excavation strategy and to proceed, instead, with a joint excavation of the top heading and bench during the first stage, followed by the invert excavation in the second stage. Numerical results confirmed that a $4 \mathrm{~m}$ excavation stage for the invert ( $2 \mathrm{~m}$ stage was predicted) is the minimum allowable value preventing a collapse of the tunnel due to excessive strains. The analysis of an optimum stage for the excavation progress showed that in some cases stages can be longer than designed. Nevertheless, the decision whether to assume certain geotechnical risks depend on the contractor's experience. Increasing the excavation stage length shortens the construction time and reduces the project costs. Good predictions are possible only with $3 \mathrm{D}$ numerical simulations of the tunnel excavation, associated with experience, intuition and field measurements. Such approach results not only in the reduction of project costs but also in the improvement of work performance and safety.

Data collected by geotechnical measurements, which is frequently kept unused in archives, should be used in the future for the need of similar stress and strain analyses, in order to combine empirical knowledge with results of numerical calculations. The main goal of the analysis described was to determine the level of agreement between numerical results and field measurements. Additionally, a backward analysis of the excavated tunnel is particularly important for the verification of design parameters and the excavation method used.

\section{References}

[1] Civil Engineering and Development Department Catalogue of Notable Tunnel Failure Case Histories. Hong Kong Special Administration Region Government, 2009.

[2] Frgić, L.; Jaguljnjak-Lazarević, A.; Hrestak, T. Numeričko modeliranje iskopa podzemnih prostorija. // Istraživanje, eksploatacija i prerada čvrstih mineralnih sirovina, Međunarodni rudarski simpozij / Dubrovnik, 2006, pp. 140145.

[3] Fotodokumentacija tunela Sleme. // Viadukt / Zagreb, 1995-2008.

[4] Tunel Sleme - desna cijev. // Glavni projekt /IPZ Zagreb, 2005.

[5] Tunel Sleme - desna cijev. // Geotehnički projekt / IGH Zagreb, 2005.

[6] Hoek E. Numerical Modelling for Shallow Tunnels in Weak Rock. URL: http://www.rocscinence.com/library/ rocnews/Spring2003/ShallowTunnels.pdf (01.04.2008)

[7] Hrestak, T. Doprinos osiguranju iskopa tunela s malim nadslojem. // Doktorski rad, Sveučilište u Zagrebu Rudarsko-geološko-naftni fakultet, Zagreb, 2010.

[8] Hrestak, T. Moderne tehnike iskopa tunela u slabim stijenama i njihova primjenjivost u Hrvatskoj. // Magistarski rad, Sveučilište u Zagrebu Rudarsko-geološkonaftni fakultet, Zagreb, 2000.
[9] Hudec, M. Primjena principa graničnih stanja u tunelogradnji. // Građevinar. 52, 8(2000), pp. 443-450.

[10] Kovačević, M. S.; Lušo, P.; Kuželički, R. Povratne numeričke analize u tunelu Pećine. // Ojačanje tla i stijena, Priopćenja 4. savjetovanja Hrvatskog geotehničkog društva / Opatija, 2006, pp. 508.

[11] Likar, J.; Volkmann, G.; Button, E. New Evaluation Methods in Pipe Roof Support Tunnels and its Influence on Design During Construction. // Proceedings EUROCK 2004, Salzburg, 2004, pp. 277-282.

[12] Lunardi, P. The Design and Construction of Tunnels using the Approach Based on the Analysis of Controlled Deformation in Rocks and Soils. // Tunnels and Tunnelling International. Supplementospeciale, May 2000.

[13] Muraki, Y. The Umbrella Method in Tunnelling. Master Thesis, Massachusetts Institute of Technology, 1997.

[14] Plaxis 3D Tunnel version 2. // Manuals /Plaxis B.V., 2004.

[15] Sage - Crisp 4. // Users Manual / CRISP Consortium, 2000.

[16] Stojković, B.; Stanić, B.; Kovačević, M. S. Metodologija geotehničkog projektiranja tunela Sveti Marko. // Građevinar. 53, 8(2001), pp. 507-516

\section{Authors' addresses}

Tomislav Hrestak, PhD

Viadukt d.d.

Kranjčevićeva 2, 10000 Zagreb, Croatia

E-mail: Tomislav.Hrestak@viadukt.hr

\author{
Antonia Jaguljnjak Lazarević, PhD, Assistant Professor \\ University of Zagreb, Faculty of Mining, \\ Geology and Petroleum Engineering \\ Pierottijeva 6, 10000 Zagreb, Croatia \\ E-mail: antonia.jaguljnjak-lazarevic@rgn.hr
}

Lidija Frgić, PhD, Professor University of Zagreb, Faculty of Mining, Geology and Petroleum Engineering Pierottijeva 6, 10000 Zagreb, Croatia

E-mail: lidija.frgic@rgn.hr 